\title{
RESPONSE OF Magnolia grandiflora L. SEEDLINGS TO FOLIAR APPLICATION OF MAGNESIUM, ZINC AND BORON
}

(Received:31.5. 2010)

\author{
By \\ S. S. Sakr, M. A. El-Khateeb, F.E.M. El-Quesni" and H. M. Abd El-Magied* \\ Ornamental Horticulture Department, Faculty of Agriculture, Cairo University, Giza, Egypt. \\ "Ornamental Plants and Woody Trees Department, National Research Center, Dokki. Giza, Egypt
}

\begin{abstract}
A pot experiment was carried out in the glass house of the Experimental Nursery of Ornamental Horticulture Department, Cairo University, Giza during 24 months -After a month from transplantingfrom 2006 to 2008. The aim of this study was to investigate the response of Magnolia grandiflora L. seedlings to foliar spray with magnesium at 25 and $50 \mathrm{ppm}$, zinc at 25 and $50 \mathrm{ppm}$ and boron at 10 and 20 ppm. Data recorded on vegetative growth such as plant height, stem diameter, leaf area, number of leaves/plant, fresh and dry weights of leaves, stems and roots and root length were significantly affected by the aforementioned treatments which were used in this study. As well as all the treatments of magnesium, zinc and boron had a clear effect on the chemical composition such as chlorophyll-a, b, carotenoids $\mathrm{mg} / \mathrm{gm} \mathrm{F.W.} \mathrm{in} \mathrm{the} \mathrm{leaves,} \mathrm{carbohydrates} \mathrm{\%} \mathrm{D.W.} \mathrm{in} \mathrm{the} \mathrm{different} \mathrm{organs} \mathrm{of} \mathrm{plants} \mathrm{and} \mathrm{the}$ contents of nitrogen, phosphorus and potassium \% D.W. in the different organs of Magnolia grandiflora L. seedlings, as compared with control treatment in most cases. Foliar application of $\mathrm{Mg}$ at $25 \mathrm{ppm}$ significantly promoted plant height, $\mathrm{Zn}$ at the rate of $50 \mathrm{ppm}$ gave the highest values of stem diameter, leaf area, number of leaves/plant as well as $\mathrm{Mg}$ at $50 \mathrm{ppm}$ produced the tallest root length, compared with control plants. Fresh and dry weights of the plant organs were significantly affected by application of the aforementioned application of treatments, compared with control plants. Chemical constituents, i.e., chlorophyll (a), chlorophyll (b), caroteniods, mineral content of N, P and $\mathrm{K} \%$ and total carbohydrate content of different plant organs were increased by application of the aforementioned treatments as compared with the control .
\end{abstract}

Key words: boron (B), foliar application, magnesium (Mg), magnolia grandiflora L., zinc (Zn).

\section{INTRODUCTION}

Magnolia trees (Magnolia grandiflora L.) are large, broad-leaved evergreen trees that can grow $18-27 \mathrm{~m}$ in height with a trunk up to $0.6-0.9 \mathrm{~m}$ in diameter (Radford et al. 1968). It has been planted for a shade and as ornamental tree in gardens, houses and along streets, etc (Milne and Milne, 1975). Magnolia is widely planted as an ornamental tree because of its showy, fragrant, ivory flowers and large evergreen leaves and the wood is limited in its uses, but may be made into furniture, paneling, veneer, creates, and cabinets (Brown and Kirman,1990). Magnolia trees (Magnolia grandiflora L.) Mangnolia belongs to Family Magnoliaceae. There are more than 100 cultivars common and native to North America (Odenwald and Turner, 1996).

Micronutrients are the elements a plant requires for proper growth but because these elements are needed in small amounts, they are often referred to as micronutrients (Kohnk and
Franzmier, 1995). There are many beneficial effects of macro and micro elements on plants and their involvement in the other processes, carbohydrate and nitrogen metabolism, as well as resistance of plant to diseases and adverse environmental conditions. Macro and micro elements are also essential for the organization and rapid alternation of nutrition compounds within the plant owing to their great importance in contribution to direct the enzymes way in metabolism (Marschner, 1995 and Massoud et al. 2005). Mosquera et al. (2002) found that foliar application of zinc at the rate of $50 \mathrm{ppm}$ stimulated the vegetative growth of Hedera helix plants. Khalil et al. (2002) on Tagetes erecta, L. stated that the combined effects of compost and $\mathrm{Zn}+\mathrm{Mn}$ recorded the best results on chlorophyll $\mathrm{a}, \mathrm{b}$, carotenoids content, total carbohydrates, $\mathrm{N}$, P, and K content. Dorgham (2005) on Dieffenbachia and Syngonium podophylum, found that spraying with $\mathrm{Mg}$ and $\mathrm{B}$ gave the tallest 
plants ,thickest stems, and increased the number of leaves, leaf area, fresh and dry weights of stems, leaves and roots. Also, the treatment with $\mathrm{Mg}$ at the rate of $50 \mathrm{ppm}$ gave the highest values of chlorophyll, total carbohydrates, phosphorus and magnesium in the leaves. Mazhar et al. (2006) on Taxodium disticum, observed that all growth parameters as well as the total sugars, chlorophyll $\mathrm{a}, \mathrm{b}$ and carotenoids tended to increase by increasing the concentration of boron up to 20 ppm as compared with the untreated one. Farahat et al. (2007) on Cupressus sempervirens L. revealed that, $\mathrm{Zn}$ at $40 \mathrm{ppm}$ application significantly increased all tested morphological parameters compared with those obtained by low level $(20 \mathrm{ppm})$ and untreated plant. Also, they found that spraying the plants with $\mathrm{Zn}$ gradually increased pigment content of leaves, total soluble sugars as well as $\mathrm{N}, \mathrm{P}$ contents in the leaves by increasing $\mathrm{Zn}$ concentration from 20 to $40 \mathrm{ppm}$.

The present study was conducted aiming at investigating the effect of Magnesium $(25,50$ $\mathrm{ppm})$, Zinc $(25,50 \mathrm{ppm})$ and Boron at $(10,20$ $\mathrm{ppm})$ treatments on the vegetative growth and some chemical constituents of Magnolia grandiflora L. seedlings. The information provided by this study may help in elucidating the response of $M$. grandiflora for the applications of these elements.

\section{MATERIALS AND METHODS}

The present study was carried out in the greenhouse of the Experimental Nursery of Ornamental Horticulture Department, Faculty of Agriculture, Cairo University, Giza, during 24 months-After a month from transplanting- from April, 2006 to April, 2008.

The objective of this study was to investigate the response of Magnolia grandiflora L. seedlings to magnesium and some trace elements (zinc and boron) on growth and chemical constituents.

Uniform seedlings of Magnolia grandiflora L. plants. (obtained from Forestry Department, Horticulture Research Institute, Agricultural Research Centre, Giza) with an average of $4-5$ leaves and $12-16 \mathrm{~cm}$ height were used in this investigation.

On the $8^{\text {th }}$ of March, 2006 the small plants were transplanted in plastic pots of $20 \mathrm{~cm}$ in diameter filled with a mixture of peat moss + sand + clay $(1: 1: 1 \mathrm{~V} / \mathrm{V} / \mathrm{V})$. After a month from transplanting a mixture of NPK (1:1:1) at $2 \mathrm{gm} / \mathrm{pot}$ was added at monthly intervals, the plants were sprayed with the solution of nutritional elements until run off point; the treatment was applied every two month intervals. Bio-film agent was added at $1 \mathrm{ml} / \mathrm{l}$ to the solution as a wetting agent for the different treatments. The seedlings received a regular irrigation.

Magnesium, zinc and boron nutrient solutions were prepared using the following salts, as sources for magnesium, zinc and boron: -

-Magnesium $(\mathrm{Mg})$ at 25 and $50 \mathrm{ppm}(\mathrm{Mg}$ chelated, EDTA 12\%).

-Zinc ( $\mathrm{Zn})$ at 25 and $50 \mathrm{ppm}(\mathrm{Zn}-$ chelated, EDTA $13 \%)$.

-Boron (B) at 10 and $20 \mathrm{ppm}$ (borax 11.4\%).

After 24 months from transplanting the following data were recorded: plant height $(\mathrm{cm})$, stem diameter $(\mathrm{mm})(5 \mathrm{~cm}$ from soil surface), leaf area $\left(\mathrm{cm}^{2}\right)$ (using leaf area meter) and number of leaves / plant, fresh and dry weights of leaves, stems and roots (gm/plant), root length $(\mathrm{cm})$, chlorophyll a \& b and caroteniods contents in leaves (mg/gm. F.W.), total carbohydrates content in leaves, stems and roots (\%D. W.) and nitrogen, phosphorus and potassium contents in the leaves, stems and roots (\%D. W.)

The different foliar treatments of $\mathrm{Mg}, \mathrm{Zn}$ and $B$ were replicated three times and each replicate contained three plants ( 3 pots). The layout of the experiment was a complete randomized design. The differences between the means of the different treatments of each experiment were compared by using L.S.D. test at $5 \%$ probability (Sendecor and Cochran, 1980). Chlorophyll a, b and carotenoid contents were determined in fresh green leaves according to Wettstein (1957). Total carbohydrates content in dried material of leaves, stems and roots were determined according to Dubois et al. (1956). The content of nitrogen (\%D.W.) was determined by modified microKjeldahl method as described by Pregl (1945). Phosphorus content was determined according to Snell and Snell (1949). The content of potassium\% was determined by flame spectrophotometer according to Chapman and Pratt (1961).

\section{RESULTS AND DISCUSSION \\ 3.1. Vegetative growth \\ 3.1.1. Plant height}

The data presented in Table (1) indicate that, spraying the plants, with $\mathrm{Mg}, \mathrm{Zn}$ and $\mathrm{B}$ increased significantly the height of magnolia seedlings, compared with the control. Using $\mathrm{Mg}$ at $25 \mathrm{ppm}$, $\mathrm{B}$ at $10 \mathrm{ppm}$, and $\mathrm{Zn}$ at $50 \mathrm{ppm}$ were the best treatments in this concern compared with the other treatments. These treatments gave the tallest plants, i.e., 55.00, 52.67 and $46.00 \mathrm{~cm}$, respectively when compared with the other treatments.

The positive effect of $\mathrm{B}$ on plant height may be attributed to the role of boron on cell 
elongation (Shaaban et al. 2004). Zinc plays an important role in plant physiology, where it activates some enzymes. Zinc functions are related to metabolism of carbohydrates and proteins, which are essential multiple processes, critical to development and differentiation of cells, (Vallee, 1976). These results are in agreement with those obtained by Mazhar et al. (2006) on Taxodium disticum and Esmail (2008) on Codiaeum variegatum 'Gold Star'.

\subsubsection{Stem diameter}

The data presented in Table (1) on stem diameter of magnolia seedlings reveal that, 9.3, 9.2 and $9.2 \mathrm{~mm}$ in stem diameter were recorded due to the application of $\mathrm{Zn}$ at $50 \mathrm{ppm}, \mathrm{Mg}$ at 50 ppm and B at $20 \mathrm{ppm}$, respectively, while the control plants recorded $5.3 \mathrm{~mm}$. The results are in agreement with those obtained by Farahat et al. (2007) on Cupressus sempervirens $\mathrm{L}$.

\subsubsection{Leaf area}

As shown in Table (1), spraying the plants with $\mathrm{Mg}, \mathrm{Zn}$ and $\mathrm{B}$ significantly increased the average value of leaf area for magnolia seedlings. Treating plants with $\mathrm{Zn} 50 \mathrm{ppm}$ was the most effective for increasing the leaf area as compared with all other treatments. Also, using B at $20 \mathrm{ppm}$ and $\mathrm{Mg}$ at $25 \mathrm{ppm}$ were more effective in increasing the leaf area than the other level used; similar results were obtained by Dorgham (2005) on Dieffenbachia amoena and Syngonium podophylum plants.

\subsubsection{Number of leaves/plant}

As shown in Table (1) the data reveal that there were significant effects with application of $\mathrm{Mg}$ and trace elements ( $\mathrm{Zn}, \mathrm{B})$ on the number of leaves in most cases. The lower level of both $\mathrm{Mg}$ and $\mathrm{B}$ were more effective in increasing the number of leaves per seedling; the treatment gave 24.0 and 23.7 leaves / seedling respectively, compared to 21.0 and 20.7 leaves / seedling for the higher level. On the other hand, increasing the level of $\mathrm{Zn}$ from 25 to $50 \mathrm{ppm}$, significantly increased the number of leaves from 21.9 to 24.5 leaves / seedling, whereas the control plants produced 17.0 leaves / seedling. These results are in accordance with those obtained by Mazhar et al. (2006) on Taxodium distichum and Abd El-Aziz and Balbaa (2007) on Salvia farinacea seedlings.

\subsubsection{Fresh and dry weights of leaves}

The data in Table (2) reveal that the application of $\mathrm{Mg}$ and trace elements ( $\mathrm{Zn}$ and $\mathrm{B}$ ) significantly affected the fresh and dry weights of leaves. Concerning the effect on leaves fresh weight, it is clear that the application of $\mathrm{Mg}$ and trace elements increased the fresh weight / plant for all treatments giving the heaviest weight (53.23 $\mathrm{gm} /$ plant) for the plant treated with $\mathrm{Zn}$ at 50 $\mathrm{ppm}$ followed by $\mathrm{Mg}$ at $50 \mathrm{ppm}$ which gave $42.00 \mathrm{gm} \mathrm{/} \mathrm{plant} \mathrm{then} \mathrm{B} \mathrm{at} 10 \mathrm{ppm}$ which produced $41.42 \mathrm{gm} /$ plant as compared with the untreated plants which gave $19.35 \mathrm{gm} /$ plant. The data indicate that raising the level of both $\mathrm{Mg}$ and $\mathrm{Zn}$ from 25 to $50 \mathrm{ppm}$ had a significant effect on increasing the fresh weight of leaves. Regarding the response of leaves dry weight to the treatments, the data indicate that treating the plants with $\mathrm{Zn}$ at $50 \mathrm{ppm}, \mathrm{Mg}$ at 50 $\mathrm{ppm}$ and $\mathrm{B}$ at $10 \mathrm{ppm}$ were the most effective treatments in increasing leaves dry weights which resulted in 19.43, 18.15 and $16.11 \mathrm{gm} /$ plant, respectively, as compared with the untreated plants $7.95 \mathrm{gm} /$ plant. The application of $\mathrm{Mg}$ and $\mathrm{Zn}$ at the two levels used on magnolia seedlings were the most effective treatments on increasing the leaves dry weight as compared with the control, whereas B $20 \mathrm{ppm}$ had no significant effect on the dry weight of leaves. These results are in agreement with those obtained by El-Khateeb and El-Hanafy (2001) on Hippeastrum vittatum plants and Dorgham (2005) on Dieffenbachia amoena and Syngonium podophylum.

\subsubsection{Fresh and dry weights of stems}

The data in Table (2) show that the application of $\mathrm{Mg}$ and trace elements on magnolia seedlings had a significant effect on stems fresh weight. It is clear that the application of $\mathrm{Mg}$ and trace elements increased fresh weight of stems / plant for all treatments giving the heaviest stem weight 24.90, 20.75 and $20.21 \mathrm{gm} / \mathrm{plant}$, for the plant treated with $\mathrm{Zn}$ at $50 \mathrm{ppm}, \mathrm{Mg}$ at $50 \mathrm{ppm}$ and $\mathrm{B}$ at $20 \mathrm{ppm}$, respectively as compared with the control $3.78 \mathrm{gm} /$ plant. Regarding the effect of $\mathrm{Mg}$ and trace elements treatments on stem dry weight, the obtained data indicate that treating magnolia seedlings with $\mathrm{Zn}$ at $50 \mathrm{ppm}, \mathrm{Mg}$ at 50 ppm and $\mathrm{B}$ at $20 \mathrm{ppm}$ were the most effective, which resulted in $10.92,8.83$ and $8.60 \mathrm{gm} /$ plant, respectively, stems dry weight, as compared with the untreated plants $2.35 \mathrm{gm} /$ plant. There are many beneficial effects of micronutrients on plants and their involvement in the other processes, carbohydrate and nitrogen metabolism, as well as the resistance to diseases and adverse environmental conditions. Microelements are also essential for the organization and rapid alternation of nutrition compounds within plant owing to their great importance in contribution to direct the enzymes in metabolism (Massoud et al., 2005).These results are in agreement with Esmail (2008) on Codiaeum variegatum 'Gold Star'.

\subsubsection{Fresh and dry weights of roots}


Table (1):Effect of $\mathrm{Mg}$ and some trace elements ( $\mathrm{Zn}$ and $\mathrm{B}$ ) on some growth parameters of Magnolia grandiflora L. seedlings during 24 months from April,2006 to April,2008.

\begin{tabular}{|c|c|c|c|c|}
\hline $\begin{array}{c}\text { Growth } \\
\text { parameters } \\
\text { Treatments (ppm) }\end{array}$ & $\begin{array}{c}\text { Plant height } \\
(\mathbf{c m})\end{array}$ & $\begin{array}{c}\text { Stem } \\
\text { diameter } \\
(\mathbf{m m})\end{array}$ & $\begin{array}{c}\text { Leaf area } \\
\left(\mathbf{c m}^{2}\right)\end{array}$ & Number of leaves/plant \\
\hline Control & $\mathbf{2 5 . 3 0}$ & $\mathbf{5 . 3}$ & $\mathbf{3 3 . 6 3}$ & $\mathbf{1 7 . 0}$ \\
\hline Mg 25 & $\mathbf{5 5 . 0 0}$ & $\mathbf{8 . 3}$ & $\mathbf{8 3 . 2 3}$ & $\mathbf{2 4 . 0}$ \\
\hline Mg 50 & 45.67 & 9.2 & $\mathbf{7 2 . 8 1}$ & $\mathbf{2 1 . 0}$ \\
\hline Zn 25 & $\mathbf{3 8 . 3 3}$ & $\mathbf{8 . 0}$ & $\mathbf{6 7 . 0 6}$ & $\mathbf{2 1 . 9}$ \\
\hline Zn 50 & 46.00 & 9.3 & 93.23 & 24.5 \\
\hline B 10 & $\mathbf{5 2 . 6 7}$ & $\mathbf{6 . 0}$ & 41.54 & 23.7 \\
\hline B 20 & 39.67 & 9.2 & $\mathbf{8 8 . 3 0}$ & 20.7 \\
\hline LSD at 5\% & 2.08 & 1.3 & 3.91 & 1.6 \\
\hline
\end{tabular}

Table (2): Effect of $\mathrm{Mg}$ and some trace elements ( $\mathrm{Zn}$ and $\mathrm{B})$ on the fresh and dry weights (gm.) of leaves, stems and roots and root length for Magnolia grandiflora $\mathbf{L}$. seedlings, during 24 months from April, 2006 to April, 2008.

\begin{tabular}{|c|c|c|c|c|c|c|c|}
\hline $\begin{array}{l}\text { Characters } \\
\text { Treatments } \\
\text { (ppm) }\end{array}$ & $\begin{array}{l}\text { Fresh weight } \\
\text { of } \\
\text { leaves/plant } \\
\text { (gm) }\end{array}$ & $\begin{array}{l}\text { Dry weight of } \\
\text { leaves/plant(gm) }\end{array}$ & $\begin{array}{c}\text { Fresh } \\
\text { weight of } \\
\text { stems/plant } \\
\text { (gm) }\end{array}$ & $\begin{array}{l}\text { Dry weight of } \\
\text { stems/plant } \\
\text { (gm) }\end{array}$ & $\begin{array}{l}\text { Fresh weight } \\
\text { of roots/plant } \\
\quad \text { (gm) }\end{array}$ & $\begin{array}{c}\text { Dry } \\
\text { weight } \\
\text { of } \\
\text { roots/ } \\
\text { plant } \\
\text { (gm) }\end{array}$ & $\begin{array}{l}\text { Root } \\
\text { length } \\
(\mathrm{cm})\end{array}$ \\
\hline Control & 19.35 & 7.95 & 3.78 & 2.35 & 2.99 & 1.50 & 12.60 \\
\hline Mg 25 & 25.72 & 10.87 & 13.41 & 5.23 & 5.44 & 2.91 & 19.80 \\
\hline Mg 50 & 42.00 & 18.15 & 20.75 & 8.83 & 7.94 & 4.03 & 25.20 \\
\hline Zn 25 & 20.83 & 9.62 & 11.28 & 4.39 & 3.68 & 2.68 & 17.00 \\
\hline Zn 50 & 53.23 & 19.43 & 24.90 & 10.92 & 7.58 & 3.34 & 23.30 \\
\hline B 10 & 41.42 & 16.11 & 10.90 & 3.68 & 7.54 & 3.91 & 24.50 \\
\hline $\begin{array}{ll}\text { B } 20 \\
\end{array}$ & 25.05 & 8.96 & 20.21 & 8.60 & 3.15 & 2.15 & 16.60 \\
\hline LSD at $5 \%$ & 3.00 & 2.30 & 1.60 & 1.20 & 0.88 & 0.40 & 2.20 \\
\hline
\end{tabular}

The data in Table (2) reveal that fertilizing the plants with $\mathrm{Mg}$ and trace elements ( $\mathrm{Zn}$ and B) affected significantly in some cases the roots fresh weight, as compared with the untreated plants. Spraying the seedlings with high level of $\mathrm{Mg}$ at $50 \mathrm{ppm}, \mathrm{Zn}$ at $50 \mathrm{ppm}$ and low level of B at $10 \mathrm{ppm}$ increased significantly the roots fresh weight 7.94, 7.58 and $7.54 \mathrm{gm} \mathrm{/} \mathrm{plant,}$ respectively. Whereas, application of $\mathrm{Mg}$ at 25 $\mathrm{ppm}$ and $\mathrm{Zn}$ at $25 \mathrm{ppm}$ were less effective than the application of high levels, which resulted in 5.44 and $3.68 \mathrm{gm} \mathrm{/} \mathrm{plant,} \mathrm{respectively.}$ Concerning the effect of $\mathrm{Mg}$ and trace elements on roots dry weight, the obtained results indicated that, $\mathrm{Mg}$ at $50 \mathrm{ppm}, \mathrm{B}$ at $10 \mathrm{ppm}$ and $\mathrm{Zn} 50 \mathrm{ppm}$ resulted in 4.03, 3.91 and $3.34 \mathrm{gm} /$ plant, respectively. Similar results were reported by Farahat et al. (2007) on Cupressus sempervirens $\mathrm{L}$.

\subsubsection{Root length}

The data in Table (2) show that treating magnolia seedlings with high level of $\mathrm{Mg}$ at 50 ppm, low level of B at $10 \mathrm{ppm}$ and $\mathrm{Zn}$ at $50 \mathrm{ppm}$ increased significantly the root length which produced $25.20,24.50$ and $23.30 \mathrm{~cm}$, respectively, as compared with the control plants at $12.60 \mathrm{~cm}$. These results are in agreement with those obtained by Farahat et al. (2007) on Cupressus sempervirens $\mathrm{L}$.

\subsection{Chemical composition}

\subsection{Pigments content}

As shown in Table (3), the data indicate that $\mathrm{Mg}$ at 25, $50 \mathrm{ppm}, \mathrm{Zn}$ at 25, $50 \mathrm{ppm}$ and $\mathrm{B}$ at 10 , $20 \mathrm{ppm}$ increased the content of chlorophyll-a, than the control plants and the highest value 1.29 $\mathrm{mg} / \mathrm{gm}$ F.W. was recorded with $\mathrm{Mg}$ at $25 \mathrm{ppm}$ treatment. Also the highest content of chlorophyllb $0.83 \mathrm{mg} / \mathrm{gm}$ F.W. was produced by the application of $\mathrm{Mg}$ at $25 \mathrm{ppm}$, followed by $\mathrm{Mg}$ at $50 \mathrm{ppm} 0.80 \mathrm{mg} / \mathrm{gm} \mathrm{F.W}$. and $\mathrm{Zn}$ at $25 \mathrm{ppm}$ which resulted in $0.71 \mathrm{mg} / \mathrm{gm}$ F.W. The highest content of caroteniods in the fresh leaves of 
Table (3): Effect of $\mathrm{Mg}$ and some trace elements ( $\mathrm{Zn}$ and $\mathrm{B}$ ) on the contents of chlorophylls-a, b, carotenoids $\mathrm{mg} / \mathrm{gm} \mathrm{F} . W$. in the leaves and carbohydrates \%D.W. in the different organs of Magnolia grandiflora L. seedlings, during 24 months from April, 2006 to April, 2008.

\begin{tabular}{|c|c|c|c|c|c|c|}
\hline \multirow{2}{*}{$\begin{array}{ll}\text { Treatments } & \text { Characters } \\
(\text { ppm })\end{array}$} & \multicolumn{3}{|c|}{$\begin{array}{l}\text { Chlorophyll content } \\
\text { mg/gm F.W. }\end{array}$} & \multicolumn{3}{|c|}{ Carbohydrates \%D.W. } \\
\hline & Chl. a & Chl. b & Carotenoid & Leaves & Stems & Roots \\
\hline Control & 0.70 & 0.40 & 0.59 & 30.94 & 29.30 & 30.27 \\
\hline Mg 25 & 1.29 & 0.83 & 1.05 & 33.04 & 39.89 & 40.48 \\
\hline Mg 50 & 1.16 & $\mathbf{0 . 8 0}$ & $\mathbf{0 . 8 9}$ & 44.01 & 39.23 & 30.80 \\
\hline Zn 25 & 1.17 & 0.71 & 0.96 & 47.03 & 36.89 & 31.47 \\
\hline Zn 50 & 0.90 & 0.58 & 0.68 & 46.81 & 33.69 & 42.66 \\
\hline B 10 & 0.91 & 0.41 & 0.76 & 42.87 & 30.81 & 33.70 \\
\hline B 20 & 0.75 & 0.54 & 0.62 & 46.82 & 31.23 & 38.14 \\
\hline
\end{tabular}

Table (4):Effect of $\mathrm{Mg}$ and some trace elements $(\mathrm{Zn}$ and $\mathrm{B})$ on the contents of nitrogen, phosphorus and potassium (\% D.W.) in the different organs of Magnolia grandiflora L. seedlings, during 24 months from April, 2006 to April, 2008.

\begin{tabular}{|c|c|c|c|c|c|c|c|c|c|}
\hline \multirow{2}{*}{$\begin{array}{c}\text { Treatments } \\
\text { (ppm) }\end{array}$} & Leaves & Stems & Roots & Leaves & Stems & Roots & Leaves & Stems & Roots \\
\hline Control & 0.86 & 0.97 & 0.97 & 0.18 & 0.17 & 0.20 & 1.63 & 0.57 & 0.73 \\
\hline $\mathbf{M g} \mathbf{2 5}$ & 1.18 & 1.08 & 0.99 & 0.24 & 0.23 & 0.22 & 1.14 & 0.59 & 0.97 \\
\hline $\mathbf{M g} \mathbf{5 0}$ & 1.61 & 1.34 & 1.99 & 0.22 & 0.18 & 0.29 & 1.23 & 0.74 & 1.09 \\
\hline $\mathbf{Z n} \mathbf{2 5}$ & 1.18 & 1.29 & 1.08 & 0.21 & 0.19 & 0.22 & 1.00 & 0.68 & 1.19 \\
\hline $\mathbf{Z n} \mathbf{5 0}$ & 1.51 & 0.99 & 1.77 & 0.23 & 0.22 & 0.24 & 1.38 & 0.61 & 0.99 \\
\hline $\mathbf{B} \mathbf{1 0}$ & 1.24 & 1.09 & 1.08 & 0.27 & 0.19 & 0.21 & 1.47 & 0.58 & 1.12 \\
\hline $\mathbf{B} \mathbf{2 0}$ & 1.08 & 1.18 & 1.88 & 0.24 & 0.21 & 0.29 & 1.21 & 0.79 & 0.83 \\
\hline
\end{tabular}

magnolia seedlings $1.05,0.96$ and $0.89 \mathrm{mg} / \mathrm{gm}$ F.W. had been determined in plants treated with $\mathrm{Mg}$ at $25 \mathrm{ppm}, \mathrm{Zn}$ at $25 \mathrm{ppm}$ and $\mathrm{Mg}$ at $50 \mathrm{ppm}$, respectively, compared with the control plants which gave the lowest value $0.59 \mathrm{mg} / \mathrm{gm} \mathrm{F}$.W.

Boron at both concentrations caused an increase in chlorophyll a, b and caroteniods; boron helps transport vital sugars through plant membranes and promotes proper cell division and development. These results are in agreement with those obtained by Dorgham (2005) on Dieffenbachia amoena and Syngonium podophylum plants.

\subsubsection{Total carbohydrates content (\%D.W.)}

The effect of $\mathrm{Mg}, \mathrm{Zn}$ and $\mathrm{B}$ on the contents of the carbohydrates in the different parts of magnolia seedlings, as shown in Table (3) indicates that the highest contents of total carbohydrates in the leaves were produced, 47.03, 46.82, 46.81 and $44.01 \%$ D.W. resulted from treated seedlings with $\mathrm{Zn} 25 \mathrm{ppm}, \mathrm{B} 20 \mathrm{ppm}, \mathrm{Zn}$ $50 \mathrm{ppm}$ and $\mathrm{Mg} 50 \mathrm{ppm}$, respectively, compared with untreated plants (30.94 \%D.W.).Concerning, the effect of $\mathrm{Mg}, \mathrm{Zn}$ and $\mathrm{B}$ on total carbohydrates in stems, the data reveal that the application of $\mathrm{Mg}$ at $25 \mathrm{ppm}$ and $50 \mathrm{ppm}$ resulted in the highest carbohydrates content in the stem 39.89 and $39.23 \%$ D.W., respectively, This was followed by the treatment of $\mathrm{Zn}$ at $25 \mathrm{ppm}$ and $\mathrm{Zn}$ at 50 ppm, resulting in 36.89 and $33.69 \%$ D.W., respectively. The treatments of $B$ at 10 and $20 \mathrm{ppm}$ cause slightly increase in carbohydrates of stem, compared with control plants. In case of the roots, the application of $\mathrm{Zn}$ at $50 \mathrm{ppm}, \mathrm{Mg}$ at $25 \mathrm{ppm}$ and $\mathrm{B}$ at $20 \mathrm{ppm}$ resulted in the highest values of carbohydrates root content 42.66, 40.48 and $38.14 \%$ D.W., respectively, while the lowest values $30.27,30.80$ and $31.47 \%$ D.W were obtained with control, $\mathrm{Mg}$ at $50 \mathrm{ppm}$ and $\mathrm{Zn}$ at 25 $\mathrm{ppm}$, respectively.These results are in agreement with those obtained by Sakr (2001) on Iris tingitana plant and Dorgham (2005) on Dieffenbachia amoena and Syngonium podophylum plants.

3.2.3. Nitrogen, phosphorus and potassium contents

\subsubsection{Nitrogen content (\%D.W.).}

The data in Table (4) show great variable effects on the content of nitrogen in the different parts of magnolia seedlings.

In the leaves, the determined values showed that application of $\mathrm{Mg}$ at $50 \mathrm{ppm}, \mathrm{Zn}$ at $50 \mathrm{ppm}$ 
and $\mathrm{B}$ at $10 \mathrm{ppm}$ increased the $\mathrm{N} \%$; i.e. $1.61,1.51$ and $1.24 \%$, respectively, as compared with other treatments. The other treatments varied in their effect, giving its lowest value $1.08 \%$ for B at 20 ppm, 1.18 and $1.18 \%$ for $\mathrm{Mg}$ at $25 \mathrm{ppm}$ and $\mathrm{Zn}$ at $25 \mathrm{ppm}$, respectively as compared with the control plants $(0.86 \%)$.

In the stem, the highest values of nitrogen contents $1.34,1.29$ and $1.18 \%$, resulted in $\mathrm{Mg}$ at $50 \mathrm{ppm}, \mathrm{Zn}$ at $25 \mathrm{ppm}$ and $\mathrm{B}$ at $20 \mathrm{ppm}$ respectively than untreated plants $0.97 \%$.

In the roots, the determined values for $\mathrm{N}$ content $\%$ were the highest $1.99,1.88,1.77,1.08$, 1.08 and $0.99 \%$ resulted from $\mathrm{Mg}$ at $50 \mathrm{ppm}, \mathrm{B}$ at $20 \mathrm{ppm}, \mathrm{Zn}$ at $50 \mathrm{ppm}, \mathrm{Zn}$ at $25 \mathrm{ppm}, \mathrm{B}$ at 10 $\mathrm{ppm}$ and $\mathrm{Mg}$ at $25 \mathrm{ppm}$, respectively compared with the control plants which produced $0.97 \%$ nitrogen content in the roots of magnolia plants.

\subsubsection{Phosphorus content (\%D.W.)}

The results in Table (4) reveal that, treating the plants with $\mathrm{B}$ at $10 \mathrm{ppm}, \mathrm{B}$ at $20 \mathrm{ppm}, \mathrm{Mg}$ at $25 \mathrm{ppm}, \mathrm{Zn}$ at $50 \mathrm{ppm}, \mathrm{Mg}$ at $50 \mathrm{ppm}$ and $\mathrm{Zn}$ at $25 \mathrm{ppm}$ increased the phosphorus content of the leaves, i.e., $0.27,0.24,0.24,0.23,0.22$ and $0.21 \%$, respectively as compared with the control plants which produced $0.18 \%$.

Whereas treating the plants with levels of $\mathrm{Mg}$, $\mathrm{Zn}$ and $\mathrm{B}$ increased the phosphorus content of the stems, as compared with the control plants. Also, in roots, the same trend was found in phosphorus content and the highest phosphorus content 0.29 and $0.29 \%$ were produced with $\mathrm{Mg}$ at $50 \mathrm{ppm}$ and $\mathrm{B}$ at $20 \mathrm{ppm}$, respectively.

\subsubsection{Potassium content (\%D.W.)}

The data in Table (4) reveal that the content of potassium in the leaves of treated plants was decreased as a result of using all levels of $\mathrm{Mg}$, $\mathrm{Zn}$ and $\mathrm{B}$, compared with the control plants $0.73 \%$. Whereas treating the plants with $\mathrm{B}$ at 20 ppm, $\mathrm{Mg}$ at $50 \mathrm{ppm}, \mathrm{Zn}$ at $25 \mathrm{ppm}, \mathrm{Zn} 50 \mathrm{ppm}, \mathrm{Mg}$ $25 \mathrm{ppm}$ and B $10 \mathrm{ppm}$ resulted in $0.79,0.74$, $0.68,0.61,0.59$ and $0.58 \%$, respectively in content of the stems of magnolia plants, compared with the control plants which produced $0.57 \%$. The content of $\mathrm{K}$ in the roots, reached to the highest value at the low level of $\mathrm{Zn} 25 \mathrm{ppm}$, B $10 \mathrm{ppm}$ and $\mathrm{Mg} 50 \mathrm{ppm}$; i.e., 1.19, 1.12 and $1.09 \%$, respectively compared with the control plants $0.73 \%$.

The formentioned results are in agreement with those obtained by El-Khateeb and ElHanafy (2001) on Hippeastrum vittatum plants, Hussien (2004) on Iris plant, Dorgham (2005) on Dieffenbachia amoena and Syngonium podophylum plants and Khalil et al. (2002) on Tagetes erecta, L.

\section{Conclusion}

It could be stated that the foliar application of $\mathrm{Zn}$ at $50 \mathrm{ppm}$ was the most effective treatment for increasing the stem diameter, leaf area, number of leaves/plant and fresh and dry weights of leaves and stems. Spraying the seedling with high level of $\mathrm{Mg}$ at $25 \mathrm{ppm}$ increased the pigments content in the fresh leaves (chlorophyll A\&b and caroteniods).

Treating the seedling with $\mathrm{Mg}$ at 50ppm increased nitrogen contents in leaves,stems and roots,also increased the phosphorus contents in roots.

Whearas the content of potassium in the stems, reached the heighest value when treated with B at $20 \mathrm{ppm}$.

\section{REFERENCES}

Abd El-Aziz, Nahed, G. and Balbaa, Laila, K. (2007). Influence of tyrosine and zinc on growth, flowering and chemical constituents of Salvia farinacea L. Plants. J. Appl. Sci. Res., 3(11): 1479-1489.

Brown C. and Kirman K. (1990). Trees of Georgia and Adjacent States. Timber Press, INC. Portland, ISBN 0-88192-148-3.

Chapman H.D. and Pratt P.F. (1961). Methods of Analysis for Soils, Plant and Water. Div. of Agric. Sci. Univ. of Calif., USA,: 309 pp.

Dorgham A. H. (2005). Physiological studies on Dieffenbachia, Philodendron and Syngonium plants. M.Sc. Thesis, Fac. Agric., Cairo Univ., Egypt, 193 pp.

Dubois M., Smith F. ,Gilles K.A. ,Hamilton J.K. and Rebers P.A. (1956). Colorimetric method for determination of sugars and related substances. Anal. Chem., 28: 350-356.

El-Khateeb M.A. and El-Hanafy S.M.M. (2001). Effects of nitrogen and trace elements on growth, flowering and chemical composition of Hippeastrurn vittatum .Bull. Fac. Agric. AlAzhar Univ., No. 20:169-188.

Esmail S.A. (2008). Physiological Studies on Croton Plant. M.Sc. Thesis, Fac. Agric., Cairo Univ.; Egypt, 131 pp.

Farahat M.M., Ibrahim Soad, Taha Lobna S. and El-Quesni Fatma E.M., (2007). Response of vegetative growth and some chemical constituents of Cupressus sempervirens L. to foliar application of ascorbic acid and zinc at Nubaria. World J. of Agric. Sci., 3(3): 282-288.

Hussein H.M. (2004). Physiological Studies on Iris Plants. M.Sc. Thesis, Fac. Agric., Cairo Univ., Egypt, 152pp.

Khalil M.Y., Naguib N.Y. and El-Sherbeny S.E. (2002). Response of Tagetes erecta, L. to compost and foliar application of some microelements. Arab Universities Journal of 
Agricultural Sciences., Ain Shams Univ., Cairo, 10(3): 939-964.

Kohnk H. and Franzmier D. (1995). Soil Science Simplified. USA: Waveland Press Inc.

Marschner H. (1995). Mineral Nutrition of Higher Plants. $2^{\text {nd }}$ ed. Academic Press, Harcout Brace \& Co., Publishers.

Massoud A.M., Abou Zeid M.Y. and Bakry M.A. (2005). Response of pea plants grown in silty clay soil to micronutrients and rhizobium incubation. Egypt. J. Appl. Sci., 20: 329-346.

Mazhar Azza A.M., Zaghloul Saher and Yassen A.A.(2006). Impact of boron fertilizer on growth and chemical constituents of Taxodium disticum grown under water regime world, J. of Agric. Sci., 2: (4). 412-420.

Milne L. and Milne M. (1975). Living Plants of the World. Chanticleer Press. New York.

Mosquera M.R., López M.L., Iglesias R., Fernández E., Fernández S., Jardón B. and Rigueiro A. (2002). Micronutrient content of main natural herbs, shrubs and forage trees in NW Spain. Proceedings of the $19^{\text {th }}$ General Meeting of the European Grassland Federation, La-Rochelle, France, 27-30-May-2002; 88-89.

Odenwald N. and Turner J. (1996). Identification, Selection and Use of Southern Plants for Landscape Design. Claitor's Publishing Division. Baton Rouge, LA. $3^{\text {rd }}$ ed. 660 pp.
Pregl F. (1945). Quantitative Organic Microanalysis. $4^{\text {th }}$ Ed., J. and A. Churchill, Ltd., London.556pp.

Radford A.E., Ahles H.E. and Bell.C.R. (1968). Manual of the Vascular Flora of the Carolinas. University of North Carolina. Press. Chapel Hill, NC.(ISBN 0-8078-1087-8.)

Sakr S.S. (2001). Effect of promalin and trace elements on growth and flowering of Iris tingitana L. plants. J. Agric. Sci., Mansoura University 2001, 24(5) : $2553-2570$.

Shaaban M.M., Fouly M. and Abdel-Maguid A.A. (2004). Zinc- boron relationship in wheat plants grown under low or high levels to calcium carbonate in the soil. Pak. J. of Biol. Sci., 7: 633-639.

Snedecor G.W. and Cochran W.G. (1980). Statistical Methods. $6^{\text {th }}$ ed. lowa State Univ., Press, Ames; lowa, USA. 953pp.

Snell F.D. and Snell C.T. (1949). Colorimetric Methods of Analysis. $3^{\text {rd }}$ ed. Van Nostrand, New York, USA, p 785-807.

Vallee B.L.(1976). Zinc Biochemistry; A perspective. Dept. Biol. Chem. Harvard Med. Sch., Boston, Mass, Trends Biochem. Sci., 1: 88-95.

Wettstein D. (1957). Chlorophyll lethol und dres sunbrnikr Skopiscke formivechsei der piastiden. Exptal Cell. Res.12: 4

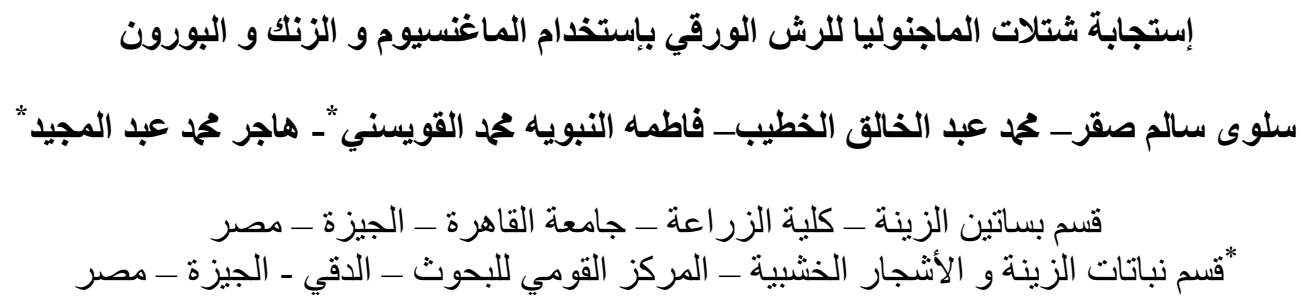

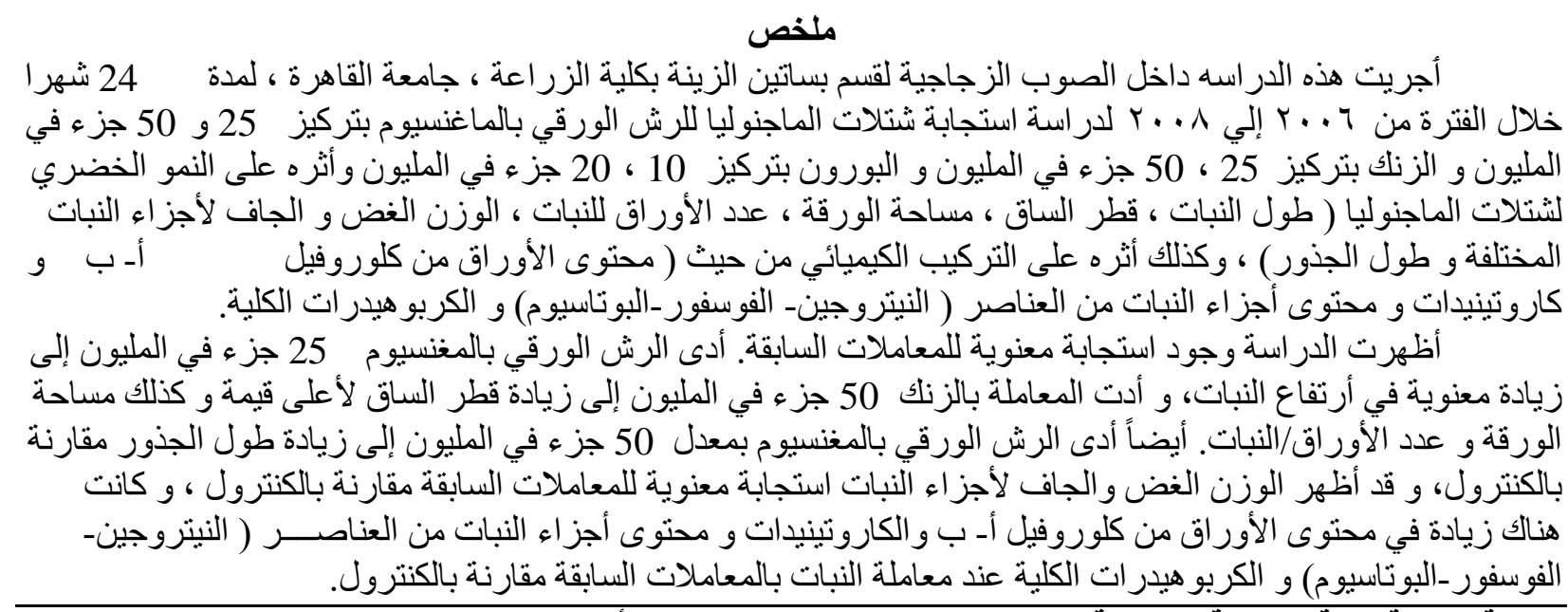

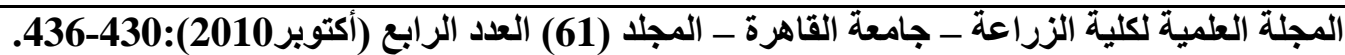

